\title{
Mixed Codes in Mindy Cake \& Cookies Recipe Book by Mindy Mot
}

\section{Ni Ketut Veri Kusumaningrum ${ }^{1 *}$}

${ }^{1}$ Bali International Polytechnic, Bali, Indonesia

A R T I C L E I N F O

Article history:

Received 9 August

z2020

Received in revised

Form 17 September

2020

Accepted 12 October

2020

Available online 01

November 2020

Keywords:

Code Mixing, Words,

Phrase

\begin{abstract}
A B S T R A C T
This study aims to find out understanding and analyzing the forms of code mixing, the types and factors of code mixing happened in this book was written by Mindy Mot. The technique of data collection used literate study. The method of this research used descriptive qualitative method. The object of this research is "The Mindy Cake \& Cookies" as a recipe book written by Mindy Mot. The result showed that there were words and phrases form of code mixing in the recipe book "Mindy Cake \& Cookies" by Mindy Mot. The type of code mixing in this book was named as code mixing out. In this book, there was no mixed code found because Mindy Mot did not insert the regional languages in her book. The writing of the recipe book used Indonesian which was inserted into English therefore it was found an only code mixing out. The factors caused the mixing of codes in "Mindy Cake \& Cookies" recipe book by Mindy Mot are the perception of the author's language background, language dominance, language attitude, psycholinguistic motivation, commercialization for the target market.
\end{abstract}

\section{Introduction}

Bilingualism is defined bilinguals as individuals who are fluent in one language but who can produce complete meaningful utterances in the other language (Appel \& Muysken, 2005; Laiman et al., 2018; Mansoer, 1987; Padmadewi et al., 2014). This definitionallows even early-stage L2 learners to be classified as bilinguals. Its has the advantage that it implies that bilingualism is someone who has acquired two languages from the start and is able to use them at the same time in speech events (Arni, 2016; Chaedar, 1985). Code mixing is the mixing of two or more languages or a variety of languages in a language act (speech act or discourse) without anything in the language situation that demands mixing of the languages (Mustikawati, 2016; Pranowo, 2014). The use of mixed codes usually occurs because in a social relationship someone masters more than one language, so that in communication various languages are used in one utterance (Fajriansyah et al., 2018; Khoirurrohman \& Anjany, 2020; Kurniasih \& Zuhriyah, 2017). The goal is that between one person and another person is more familiar and the meaning contained in communication is easier to understand.

The use of mixed codes is used in direct interaction, novels, newspapers, stories and other literary works (Ardiyanti \& Setyorini, 2018; Dewi, 2020; Fathurrohman et al., 2019). In addition, mixed codes are used in cookbooks. An example is a doctor's prescription or a cooking recipe. The recipe contains instructions on what to make, what ingredients are needed, how many ingredients are needed and how the procedure works in preparing a dish. A recipe is a set of instructions that contains instructions for making a dish. Recipes give accurate and precise instructions regarding the amount of ingredients, how to mix, prepare and work procedures for a dish, so that we can do the same thing that the recipe wants. Besides that, recipes are also a way to apply the basic techniques of specific ingredients.

In this study, researchers used the Mindy Cake \& Cookies recipe book by Mindy Mot. Researchers chose Mindy Cake \& Cookies recipe book by Mindy Mot because this book is very popular among teenagers, foodies and various circles. In 2019 the Mindy Mot recipe became one of the trending topics on Instagram and You Tube. In writing this recipe book using Indonesian interspersed with foreign languages, this has led to code mixing. In the Mindy Cake \& Cookies recipe, there are culinary terms in foreign languages that we often encounter but are difficult to translate into Indonesian. The Mindy Cake \& Cookies recipe book from the written title is in English, but the contents displayed are in Indonesian and 
some use foreign languages. The use of foreign languages certainly has its own appeal for buyers, recipe books that have attractive titles are more preferred by buyers than books that use titles according to Indonesian rules. The code mix used has played an important role in marketing this cookbook. If studied further, the use of mixed code will cause language variations. The use of language or other language elements in this recipe book is usually caused by the absence of a word equivalent in the language used to express a meaning.

Research mixed codes in cook books is important because in the world of tourism, especially culinary recipes will be more interesting if written and displayed in two or more languages (bilingual). The variety of language used will attract readers. A recipe book that uses language that is easy to understand will be easier for readers to accept. Starting from this background, the writer wants to conduct a deeper analysis of code mixing, the form of code mixing and the causes of code mixing contained in the Mindy Cake \& Cookies recipe book by Mindy Mot.

\section{Methods}

This research is a qualitative descriptive study. Descriptive method is a method used to describe or analyze a research result but is not used to make broader conclusions (Moleong, 2017; Sugiyono, 2014). The object of research was the Mindy Cake \& Cookies recipe book by Mindy Mot. Recipe book Mindy Cake \& Cookies contains 30 recipes cake, cupcake, muffin, and cookies who are taught in Mindy Mot baking classes, including baileys chocolate cake, mini chocolate vertical cake, klepon cake, victoria sponge cake, meringue lemon cake, hazelnut ferrero cake, neapolitan cake, vanilla cake, klepon cupcake, red velvet cupcake, chiffon matcha, blueberry crumble muffins, strawberry jammer cookies, gingerbread cookies, honey thin oat cookies, and others.

The type of data used in this research is qualitative data obtained from data sources, namely primary data sources and secondary data sources. Determination of data in this study was carried out by using direct quotation analysis techniques. Data collection was carried out by analysis, data cards and documentation study. The data obtained and analyzed are presented in the form of text or narrative explanation or in tabular form.

\section{Result and Discussion}

In this section the author will discuss the problems that have been formulated in the research problem formulation, namely describing the form of code mixing and the factors that cause code mixing in the Mindy Cake \& Cookies recipe book by Mindy Mot. This study analyzed 47 data containing 26 data in the form of words and 17 data in the form of phrases. Of the 26 data in the form of words, only 15 words can be stated as code mix. And from 17 data phrases, only 10 phrases can be expressed as code mix. A list of words and phrases including code mix can be seen in Table 1.

Table 1. List of Word a Phrases Including Code Mix

\begin{tabular}{cc}
\hline $\mathbf{1 5}$ words from 26 data & 10 phrases from 17 data \\
\hline Baking & Baking Soda \\
Chiffon & Overmix \\
Muffin & Buttercream \\
Cake & Whipping Cream \\
Mixer & Buttercream Baileys \\
Spatula & Baileys Buttercream \\
Stainless & Cake Emulsifier \\
Fresh & Cream Cheese \\
Frosting & Brown Sugar \\
Meringue & \\
Filling & \\
Raspberry & \\
Whisk & \\
Crumble & \\
Feezer & \\
\hline
\end{tabular}


In the study of the Mindy Cake \& Cookies recipe book, 5 factors were found to cause code mixing. The factors that cause code mixing in the Mindy Cake \& Cookies recipe book are: (a) perceptions of the author's language background, (b) language dominance, (c) language attitudes, (d) psycholinguistic motivation, and (e) commercialization for the target market.

\section{Mixed code forms in Mindy Cake $\&$ Cookies recipe book by Mindy Mot}

Code mixing is a mixture of two or more languages in communicating. Code mixing is a shift in the use of a language or a variety of languages to another language or a variety of other languages into a writing or a conversation. The form of code mixing in this study is the insertion of tangible elements of words, phrases, expressions or idioms, word repetition, and clauses. In this study it was found that the form of code mixing contained in the Mindy Cake \& Cookies recipe book by Mindy Mot is in the form of inserting words and phrases. The Mindy Cake \& Cookies recipe book uses Indonesian as a speech tool and often uses mixed code into English.

\section{Mixed Forms of Word Insertion Code}

Insertion or insertion has several special characteristics, namely the insertion of constituents in the form of a single constituent and a structure $a b$. The insertion of a single constituent in the form of $a$ noun category word found in the Mindy Cake \& Cookies recipe book by Mindy Mot is shown by the following data.

DATA 1 : Perlengkapan untuk baking (Page 5)

DATA 2 : Loyang khusus chiffon. (Page 6)

DATA 3 : $\quad$ Loyang cupcake berukuran standar untuk 12 muffin. (Page 6)

DATA 4 : Agar adonan tidak lengket di loyang nantinya saat kita ingin mengeluarkan cakenya. (Page 6)

DATA 7 : Rata-rata untuk membuat adonan cake pasti menggunakan mixer. Bisa yang hand mixer ataupun stand mixer. (Page 6)

The word baking has the equivalent, burning; cake, the word chiffon refers to the word chiffon cake, chiffon cake is a cake with the softest texture and a large hollow resembling a sponge. A special chiffon pan can be interpreted as a baking sheet that is used specifically for cake holders with a soft and hollow texture. The word muffin means miniature cake and is classified as a dessert which has a soft, fluffy and light texture because it contains butter and egg, on top of which there is always a spread of cream or chocolate. The taste is not too sweet, sometimes even a savory version is made. The word cake has the equivalent of the word cake. The word mixer has the equivalent of the word mixer. In the Mindy Cake \& Cookies recipe book, there are many words used in recipe or culinary books. The language used for this term is English. This code mix includes exit code mix because it occurs between Indonesian and English.

DATA 8 : Jenis dan ukuran sendok spatula sangat beragam. (Page 7)

DATA 9 : Pada umumnya terbuat dari kayu, karet plastik, dan stainless. (Page 7)

DATA 11 : Mangkuk sangat diperlukan untuk mengocok adonan cake. Usahakan stainless/kaca. (Page 7)

DATA 13 : $\quad$ Belilah telur yang masih baru dan fresh. (Page8)

DATA 15 : $\quad$ Sangat cocok digunakan untuk frosting kue-kue yang bertekstur lembut. (Page9)

The code-mixing event contained in the Mindy Cake \& Cookies recipe book occurs so that the reader can easily understand the steps to make a cake described. The word spatula has the equivalent of the word spatula. Many people do not understand the spatula or know the meaning of the spatula. Mixing the code will make it easier for users or readers of the book to understand what the author is saying. The word stainless means stainless cooking objects / utensils. If written stainless steel, it will feel strange to the reader, there are many kinds of stainless objects, but if it is written as stainless, then the reader's mind will automatically use a bowl which is usually shiny and made of stainless. The word cake has the equivalent of the word cake. The word fresh has the equivalent of the word fresh. The word frosting has the equivalent of the word decoration. For the word cake, it is used to be called cake, if the first name that follows the word cake is in English, it will sound more interesting, than using Indonesian. This will also be the label of the cake being made. The words fresh and frosting are the words that must be used to describe fresh ingredients, and to make decorations on the cakes that are made.

DATA 18 : Kocok dengan mixer kecepatan tinggi hingga dingin menjadi meringue, baru masukkan unsalted butter. (Page 15)

DATA 19 : $\quad$ Potong cake cokelat menjadi 3 bagian, oles tipis dengan buttercream lalu gulung perlahan. (Page 16)

DATA 20 : $\quad$ Filling: Kocok whip cream sampai tekstur mengental lalu masukkan santan dan gula halus. (Page 18) 
DATA 21 : $\quad$ Lapisi cake dengan whip cream, taburi dengan inti kelapa atasnya. (Page 19)

DATA 22 : Taruh cake pertama di atas papan kue, beri frosting sedikit lalu taburi gula merah cincang. (Page 20)

A word is a unit of a language that contains meaning and consists of one or more morphemes and can stand alone. The word is the largest unit in morphology and is considered the smallest unit in syntax. Generally, words consist of one root word without or with an affix. The word mixer has the equivalent of the word mixer. The word meringue is a term for cake, meringue is a type of dessert in France, Switzerland and Italy. The word cake has the equivalent of the word cake. The word filling has the equivalent of a stuffing word, the content here can be fruit jam, chocolate mouse or chocolate ganache. The word cake has the equivalent of the word cake. The word frosting has the equivalent of the word decoration.

DATA 23 : $\quad$ Ambil 1 lapis cake, oleskan Nutella lalu beri vanilla buttercream (Page 24)

DATA 24: $\quad$ Oleskan cake dengan vanilla buttercream lalu tutup dengan 1 lapis cake lagi. (Page 26)

DATA 25 : $\quad$ Susun 1 lapis cake di atas cake board lalu beri frosting. Timpa dengan lapisan cake kedua. (Page 30)

DATA 28 : $\quad$ Kocok susu, selai raspberry, dan putih telur. (Page 36)

DATA 31 : Tumpuk dengan cake kedua, beri buttercream lagi lalu tumpuk dengan cake ketiga. (Page 38)

In the word above, there were cases of insertion or insertion of English words. The word cake has the equivalent of the word cake. The word frosting has the equivalent of the word decoration. The word raspberry is a fruit from the berry family that has a very beautiful shape and color. Raspberries will easily melt in your mouth because of their sweet and creamy texture.

DATA 33 : Tutupi semua cake dengan sisa frosting. (Page 44)

DATA 36 : Beri olesan vanilla cream pada lapisan cake pertama, lalu tutup dengan cake kedua. Cover seluruh cake dengan buttercream dan tutupi dengan parutan keju. (Page 52)

DATA 38 : $\quad$ Kocok dengan whisk di mangkuk terpisah, kuning telur, minyak, santan, baking powder. (Page 56)

DATA 39 : Kocok dengan whisk kuning telur, minyak, air, tepung terigu, dan matcha powder. (Page 58)

DATA 40 : $\quad$ Hancurkan menggunakan tangan semua bahan sampai berbentuk crumble. (Page 64)

DATA 44 : $\quad$ Pipihkan adonan tepung sampai setebal $0,5 \mathrm{~cm}$, lalu potong dengan ring cutter, simpan di freezer selama 15 menit. (Page 71)

In the above quote, there is a process of forming a mixed code for the insertion of foreign languages, namely by inserting an English word. Mix the code, namely the word cake, the word cake has the equivalent of the word cake. The word frosting has the equivalent of the word decoration. The word whisk has the equivalent of the word whisk. The word crumble has the equivalent of the word destroyed. The word freezer has the equivalent of the word cooler. Although sometimes the word groups already have equivalent words, this is intended by the author to make it easier for readers to use original terms that are easy to understand (Aritonang et al., 2019; Gayatri et al., 2016).

\section{Mixed Forms of Phrase Insertion Code}

Phrases are combinations of two or more words that have meaning. The insertion of phrases in the Mindy Cake \& Cookies recipe book from English into Indonesian is indicated by the following data.

DATA 5 : Untuk mengukur bahan-bahan yang berukuran kecil seperti garam, baking powder, baking soda alat ini sangat diperlukan. (Page 6)

DATA 6 : Kocokan ini sangat kita perlukan apabila kita mengocok dengan tangan agar tidak overmix dan cepat meratakan adonan. (Page 6)

Data 10 : Fungsinya untuk mengaduk adonan dan meratakan buttercream di cake. (Page 7)

DATA 14 : Whipping cream terbuat dari susu dengan lemak susu sekitar 30-40\%. (Page 9)

DATA 16 : $\quad$ Buttercream Baileys (Vanilla buttercream $740 \mathrm{~g}+200 \mathrm{~g}$ Baileys, kocok sampai rata) (Page 13)

In quotes $5,6,10,14$, and 16 above, the authors mixed the code at the phrase level. This is in line with the theory put stated that mixing codes at the phrase level is a lower level compared to mixing codes at the clause level, phrases are a combination of two or more words which are not specific (Simatupang et al., 2019; Sugiyono \& Widodo, 2017; Suwandi, 2010). The phrase baking powder has the equivalent of baking powder. The phrase baking soda has the equivalent of the word baking soda. The phrase overmix has more equivalents than normal mixes. The phrase buttercream has its butter cream equivalent. The phrase Whipping cream can be interpreted as cold whipped cream. Baileys buttercream is a cream that is 
used as a cake decoration. Baileys is a coffee-flavored alcohol drink brand and buttercream is butter that is whipped until it is pale and used for cake decoration.

DATA 17: Oles tipis dengan baileys buttercream lalu gulung perlahan, sambung terus dengan potongan cake berikutnya yang sudah diolesi dengan buttercream. (Page 14)

DATA 26 : $\quad$ Ayak tepung, baking soda, baking powder, dan vanilla. (Page 32)

DATA 27 : Ayak tepung terigu, cokelat bubuk, dan baking powder, lalu campur dengan hazelnut bubuk dan almond. (Page 34)

DATA 29 : Kocok gula, tepung terigu, cokelat bubuk, baking powder, baking soda, dan garam. (Page 36)

DATA 30 : Ambil cake cokelat lalu beri frosting vanilla buttercream. (Page 37)

The insertion of the phrase in the above quote comes from a foreign language which is inserted into the sentence that uses Indonesian (Masitoh, 2013; Rulyandi et al., 2014; Setiadi, 2017). The insertion of phrases that are meant in this code-mixing event is the insertion using non-standard language (Sugiyono \& Widodo, 2017). This will be described as follows. In the data quotation above, the same phrase as before is used. The phrase buttercream has its butter cream equivalent. The phrase baking soda has the equivalent of the word baking soda. The phrase baking powder has the equivalent of baking powder. Vanilla buttercream frosting is a culinary term in the cake-making process. The phrase used is in language which is a term in the culinary field. English word equivalents are used in this recipe book so that the sentences are not odd.

DATA 32: $\quad$ Aduk rata lalu tuang campuran baking soda dan vinegar. (Page 40)

DATA 34 : $\quad$ Ayak tepung dan baking powder, sisihkan, kocok gula, telur, dan cake emulsifier sampai mengembang. (Page 48)

DATA 35 : $\quad$ Masukkan ayakan tepung terigu, baking powder, baking soda, dan garam. (Page 50)

DATA 37 : Panggang hingga matang, bisa kita sajikan dengan 1 scoop ice cream. (Page 54)

DATA 41 : Kocok mentega, cream cheese, gula pasir, brown sugar, dan vanilla kurang lebih 2 menit. (Page66)

DATA 42 : $\quad$ Lalu masukkan tepung dan baking soda, aduk rata. (Page 66)

DATA 43 : $\quad$ Ayak tepung terigu, maizena, baking powder, dan baking soda. (Page 68)

The phrase baking soda has the equivalent of the word baking soda. The phrase baking powder has the equivalent of baking powder. The phrase cake emulsifier means cake emulsifier. The phrase cream cheese has the equivalent of the word cream cheese. The phrase brown sugar means brown sugar.

\section{Mix Code Types}

There are two types of code mixing, namely mixing code in and mixing code out. The data in the Mindy Cake \& Cookies recipe book by Mindy Mot will be analyzed based on the type of code mixing. Here's the analysis.

\section{Mix Code Out}

The words baking, chiffon, muffins, cake, baking powder, baking soda are more popularly known among culinary connoisseurs and culinary makers. The author chooses English words because it feels odd to use Indonesian. From these data it can be concluded that the type of code mixing used is outward code mixing. Mindy Mot's code-mixing is code-mixing at the word and phrase level. This can be seen in the words mixer, spatula and stainless and the phrases overmix and buttercream. The data in this study is an event of code mixing out of insertion of English into Indonesian sentences. This happens because Mindy Mot is a bilingual student who understands two languages, namely English and Indonesian. In this data, Mindy Mot besides mastering Indonesian as the original or first language, Mindy Mot also mastered English as a second language. The use of English words in sentences in this recipe book is also due to the fact that the Indonesian equivalent of words is not quite right when they are included or used in the sentence.

Initially Mindy Mot used Indonesian, but he inserted elements of a foreign language in the form of English into the sentence. Baking powder and baking soda which are cake developers are common among culinary makers, and the word raspberry has no equivalent words that are common in Indonesian. Cake is used in this sentence because the word cake is more popular than cake. The author is accustomed to using English because of the author's background, who often participates in overseas training. The choice of insertion of the word form as in the writing of Mindy Mot is a habit of Mindy Mot. These words appear spontaneously and naturally. Based on the analyzed data, the data in this study included mixed exit codes. The data is found in the words baking, chiffon, muffin, cake, baking powder, baking soda, overmix, mixer, spatula, stainless, buttercream, fresh, whipping cream, frosting, baileys buttercream, meringue, filling, raspberry, whisk, crumble, cream cheese, brown sugar, freezer. These words are inserted between 
sentences that use Indonesian in the Mindy Cake \& Cookies recipe book. In the Mindy Cake \& Cookies recipe book, there is no mixed code type found, this is because Mindy Mot does not insert regional languages in its writing. The recipe book writing used the main language of Indonesian which was inserted in English so that only mixed codes were found.

\section{Factors Causing Code Mixing}

Perceptions of the Author's Language Background

The use of English in the Mindy Cake \& Cookies recipe book is more interesting because English is often used among foodies. The recipe book writer also often studies abroad so that he is familiar with a foreign language that affects his grammar.

\section{Language Dominance}

The use of foreign terms is often used in the culinary industry, especially recipe books. The purpose of inserting a foreign language into the recipe book is not only so that it is easy to understand, but also functions to attract consumers. Code mixing was also affected because there was no other equivalent, and English was considered more practical.

\section{Attitude Language}

Mindy Mot in the Mindy Cake \& Cookies recipe book reflects a desire to create a recipe book that is easily understood by today's young generation.

\section{Psycholinguistic Motivation}

The Mindy Cake \& Cookies recipe book mixed with various Indonesian and English terms creates a unique impression on the mind of the reader. Unique here can mean strange or even cool for some people.

\section{Commercialization for Target Market}

The reason that can explain why Mindy Mot uses code mix is because Mindy Mot understands that consumers or book users dominate using Indonesian mixed with English so that consumers or book users when reading it easier to understand the recipes presented

\section{Conclusion}

There is a type of code mixing in the Mindy Cake \& Cookies recipe book by Mindy Mot, namely the outward code-mixing type. There are factors that cause code mixing in the Mindy Cake \& Cookies recipe book by Mindy Mot, namely perceptions of the author's language background, language dominance, language attitudes, psycholinguistic motivation, commercialization for the target market. Mixing the code in the Mindy Cake \& Cookies recipe book happened because the author is a multilingual person and the steps in making cakes are informal. Mix code in Mindy Cake \& Cookies recipe book is from Indonesian to foreign language (English). Furthermore, code mixing occurs at the outward code-mixing level through the insertion of word and phrase forms. Mix code into not found in the Mindy Cake \& Cookies cookbook.

\section{References}

Appel, R., \& Muysken, P. (2005). Language contact and bilingualism. Amsterdam University Press.

Ardiyanti, D., \& Setyorini, R. (2018). Analisis Campur Kode pada Lirik Lagu Jaran Goyang Dipopulerkan oleh Nella Kharisma. SAP (Susunan Artikel Pendidikan), 2(3). https://doi.org/10.30998/sap.v2i3.2451

Aritonang, D. R., Solin, M., \& Parapat, L. H. (2019). Pengembangan Kosa Kata Melalui Keterampilan Menulis Akademik Untuk Mengatasi Masalah Campur Kode Mahasiswa. Linguistik: Jurnal Bahasa Dan Sastra, 4(2), 120-130. https://doi.org/10.31604/linguistik.v4i2.120-130

Arni, A. (2016). Variasi Alih Kode Dan Campur Kode Dalam Masyarakat Dwibahasa Kajian Sosiolinguistik Pada Masyarakat Madura Di Kota Pontianak Kalimantan Barat. Jurnal Pendidikan Bahasa, 3(1), 43-57. https://doi.org/10.31571/bahasa.v3i1.174

Chaedar, A. (1985). Sosiologi Bahasa. Angkasa.

Dewi, R. (2020). Campur Kode dalam Proses Pembelajaran Bahasa Indonesia di SMA Negeri 1 Rantepao. 
Jurnal Ilmiah Wahana Pendidikan, 6(3), 432-441. https://doi.org/10.5281/zenodo.3980783

Fajriansyah, N. B., Sopianda, D., \& Kartini, C. (2018). Alih Kode Dan Campur Kode Pada Film Romeo \& Juliet Karya Andibachtiar Yusuf. Jurnal Pendidikan Bahasa Dan Sastra Indonesia, 1(4), 563-570. https://doi.org/10.22460/p.v1i4p563-570.952

Fathurrohman, H. R., Sumarwati, S., \& Hastuti, S. (2019). Bentuk Dan Fungsi Campur Kode Dan Alih Kode Pada Rubrik "Ah... tenane" Dalam Harian Solopos. Jurnal Penelitian Bahasa, Sastra Indonesia, Dan Pengajarannya, 1(2), 207-222. https://www.neliti.com/publications/54857/bentuk-dan-fungsicampur-kode-dan-alih-kode-pada-rubrik-ahtenane-dalam-harian-so

Gayatri, N. L. A., Sudiana, I. N., \& Indriani, M. S. (2016). Alih Kode Dan Campur Kode Guru Dalam Pembelajaran Bahasa Indonesia Kelas VII SMP Negeri 4 Kubutambahan. Jurnal Pendidikan Bahasa Dan Sastra Indonesia Undiksha, 4(2). https://doi.org/10.23887/jjpbs.v4i2.8141

Khoirurrohman, T., \& Anjany, A. (2020). Alih Kode Dan Campur Kode Dalam Proses Pembelajaran Di Sd Negeri Ketug (Kajian Sosiolinguistik). DIALEKTIKA Jurnal Pemikiran Dan Penelitian Pendidikan Dasar, 10(1), 362-370. https://journal.peradaban.ac.id/index.php/jdpgsd/article/view/518

Kurniasih, D., \& Zuhriyah, S. A. (2017). Alih kode dan campur kode di Pondok Pesantren Mahasiswa Darussalam. Indonesian Language Education and Literature, 3(1), 53-65. https://doi.org/10.24235/ileal.v3i1.1521

Laiman, A., Rahayu, N., \& Wulandari, C. (2018). Campur Kode Dan Alih Kode Dalam Percakapan Di Lingkup Perpustakaan Universitas Bengkulu. Jurnal Ilmiah Korpus, 2(1), 45-55. https://doi.org/10.33369/jik.v2i1.5556

Mansoer, P. (1987). Sosiolinguistik. Angkasa.

Masitoh, S. (2013). Campur Kode Bahasa Indonesia ke dalam Bahasa Jawa pada Siaran Radio Jampi Sayah di Radio SKB POP FM Gombong. ADITYA-Pendidikan Bahasa Dan Sastra Jawa, 3(1), 28-33. http://ejournal.umpwr.ac.id/index.php/aditya/article/view/662

Moleong, J. (2017). Metodologi Penelitian Kualitatif. Pt Remaja Rosdakarya.

Mustikawati, D. A. (2016). Alih Kode dan Campur Kode Antara Penjual dan Pembeli (Analisis Pembelajaran Berbahasa Melalui Studi Sosiolinguistik). Jurnal Dimensi Pendidikan Dan Pembelajaran, 2(2), 23-32. https://doi.org/10.24269/dpp.v2i2.154

Padmadewi, N. N., Merlyna, P. D., \& Saputra, N. P. H. (2014). Sosiolinguistik. Graha Ilmu.

Pranowo. (2014). Teori Belajar Bahasa: Untuk Guru dan Mahasiswa Jurusan Bahasa. Pustaka Pelajar.

Rulyandi, R., Rohmadi, M., \& Sulistyo, E. T. (2014). Alih Kode dan Campur Kode dalam Pembelajaran Bahasa Indonesia di SMA. Paedagogia, 17(1), 27-39. https://doi.org/10.20961/paedagogia.v17i1.36030

Setiadi, D. (2017). Campur Kode Dalam Lirik Lagu “Kis Band.” RETORIKA: Jurnal Ilmu Bahasa, 3(1), 1-15. https://doi.org/10.22225/jr.3.1.92.1-15

Simatupang, R. R., Rohmadi, M., \& Saddhono, K. (2019). Tuturan dalam pembelajaran Bahasa Indonesia (kajian sosiolinguistik alih kode dan campur kode). Kajian Linguistik Dan Sastra, 3(2), 119-130. https://doi.org/10.23917/kls.v3i2.5981

Sugiyono. (2014). Metode Penelitian Pendidikan Pendekatan Kuantitatif, Kualitatif, dan R\&D. Alfabeta.

Sugiyono, S., \& Widodo, M. (2017). Alih Kode Dan Campur Kode Di Lingkungan Sma Negeri 1 Pagelaran. JSIMBOL (Bahasa, Sastra, Dan Pembelajarannya), http://jurnal.fkip.unila.ac.id/index.php/BINDO/article/view/12336

Suwandi, S. (2010). Serba Linguistik (Mengupas Pelbagai Praktik Bahasa). Universitas Sebelas Maret Press. 